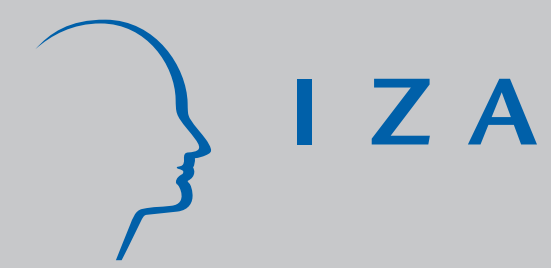

IZA DP No. 611

Some Thoughts on Macroeconomic Fluctuations and the Timing of Labor Market Reform

Gilles Saint-Paul

October 2002 


\title{
Some Thoughts on Macroeconomic Fluctuations and the Timing of Labor Market Reform
}

\author{
Gilles Saint-Paul \\ IDEl, Université de Toulouse I, \\ CEPR and IZA Bonn \\ Discussion Paper No. 611 \\ October 2002 \\ IZA \\ P.O. Box 7240 \\ D-53072 Bonn \\ Germany \\ Tel.: +49-228-3894-0 \\ Fax: +49-228-3894-210 \\ Email: iza@iza.org
}

This Discussion Paper is issued within the framework of IZA's research area Welfare State and Labor Market. Any opinions expressed here are those of the author(s) and not those of the institute. Research disseminated by IZA may include views on policy, but the institute itself takes no institutional policy positions.

The Institute for the Study of Labor (IZA) in Bonn is a local and virtual international research center and a place of communication between science, politics and business. IZA is an independent, nonprofit limited liability company (Gesellschaft mit beschränkter Haftung) supported by the Deutsche Post AG. The center is associated with the University of Bonn and offers a stimulating research environment through its research networks, research support, and visitors and doctoral programs. IZA engages in (i) original and internationally competitive research in all fields of labor economics, (ii) development of policy concepts, and (iii) dissemination of research results and concepts to the interested public. The current research program deals with (1) mobility and flexibility of labor, (2) internationalization of labor markets, (3) welfare state and labor market, (4) labor markets in transition countries, (5) the future of labor, (6) evaluation of labor market policies and projects and (7) general labor economics.

IZA Discussion Papers often represent preliminary work and are circulated to encourage discussion. Citation of such a paper should account for its provisional character. A revised version may be available on the IZA website (www.iza.org) or directly from the author. 
IZA Discussion Paper No. 611

October 2002

\section{ABSTRACT}

\section{Some Thoughts on Macroeconomic Fluctuations and the Timing of Labor Market Reform*}

In this paper, I analyze the pros and cons of implementing structural reforms of the labor market in booms vs. recessions, in light of considerations of social efficiency, political viability, and macroeconomic fine tuning. While the optimal timing of a reform depends on the relative importance of several conflicting effects, it seems clear that a reform should be accompanied by an expansionary macroeconomic policy. This makes structural reform more problematic in the context of the European Monetary Union.

JEL Classification: E32, E52, E61, J6, K31

Keywords: labour market reforms, unemployment, employment protection, monetary union, firing costs, political economy

Corresponding author:

Gilles Saint-Paul

IDEI, Université des Sciences Sociales

Manufacture des Tabacs

Allée de Brienne

31000 Toulouse

France

Tel.: (33) 561128544

Fax: (33) 561225563

Email: gilles.saint-paul@univ-tlse1.fr

* Presented at an invited lecture for the International Economic Association congress, Lisbon, September 2002. 
It is commonly heard that expansionary times are more favorable for implementing structural reforms in the labor market than recessions. Behind this belief is the intuition that structural reforms are "painful" and that such pain is likely to be lighter in a boom. In this paper I try to discuss these issues from a more precise and analytical perspective. I will conclude that this simplistic view should be severely qualified.

First of all, what do we mean by structural reforms? In the European context, this means changing one of the many regulations which hamper the functioning of the labor market and have led to an abnormally high level of unemployment and its duration. But when and how to undertake a reform of one of these institutions will differ across institutions. For example, one may plausibly argue that a reduction in the minimum wage is best implemented in a slump, because it is when wage moderation and job creation are most needed. On the other hand, it is better to engineer a reduction in unemployment benefits during a boom, because one may think that the need for insurance against job loss is less felt during a boom.

Second, what do we mean by "should", "best", "better", or "painful"? Are we talking about the optimal timing of a reform which one has decided to undertake in any case? Or are we saying that a structural reform may be desirable if the economy is in one macroeconomic situation, but not if it is in another? And, better for whom? Are we talking about what is optimal with respect to some concept of aggregate social welfare, or about what is politically viable, i.e. what is most likely to be accepted by powerful social groups?

For these reasons, we shall ask three questions:

1. Given that a reform should take place, what is the welfare maximizing timing for its implementation, in light of macroeconomic evolution?

2. What is the phase in the business cycle when the political support for a given reform is the strongest?

3. Given that a given reform takes place at a given date, what is the most appropriate macroeconomic policy in order to accompany that reform? 


\section{The case of employment protection}

As was already said, the conclusions that we draw strongly depend on which reform we are considering. I will therefore focus my discussion by restricting it on a reduction in employment protection, which is one of the most controversial regulations. While some of my arguments will also apply to other institutions, and while I will incidentally discuss some other reforms, the general conclusions that one may draw regarding the optimal timing of reductions in firing costs need not apply to other structural reforms.

According to modern economic theory, the impact of a reduction in the strictness of employment protection legislation on the economy is threefold. ${ }^{2}$ First, there is a lump of destruction of non productive jobs, that did exist only because it was less costly for firms to go on losing money on these positions than close them and pay the dismissal costs. Workers who are affected by such prospects are likely to oppose the reform, unless they are compensated. Second, by reducing total labor costs, which reflect expected future dismissal costs as well as expected foregone profits due to the likelihood of keeping workers in unprofitable positions, a reduction in employment protection increases job creation and labor market tightness. Note that the net effect of such a reduction on the level of unemployment is unclear, since we have both an increase in job creation and an increase in job destruction. However, the effect on unemployment duration is unambiguous: it falls. Third, wages increase at least after a while, reflecting a tighter labor market due to an increase in job creation. This increase in wages is also the counterpart of the fact that people are more productive, since unproductive jobs which used to be maintained because of the firing costs are now suppressed.

With these mechanisms in mind, we can now try and address the three questions asked above. Let us start with the first one, i.e. that of the appropriate timing. A natural argument could be that, since the impact effect of reductions in employment protection is a lump of job destruction, their social cost is likely to be lower in booms. This argument, unfortunately, ignores many other effects, and it is not even clear that the one it insulates goes in the right direction.

\footnotetext{
${ }^{2}$ For the relevant literature, the reader may refer to Bentolila and Bertola (1990), Hopenhayn and Rogerson (1993), Bertola (1994), Saint-Paul (1995,1997,2002).
} 


\section{Social welfare and the timing of reform}

First, it focuses on the effect of the reform on those who lose their jobs, ignoring its effects on the unemployed and on those who keep their jobs. The former, who benefit from the reform because of a greater job creation rate, may gain more if it is implemented in a slump. It all depends on the cross effect of business cycles and deregulation on job creation. As for the employed who keep their jobs, they are affected through wages, which themselves react to labor market tightness, and the same ambiguities apply.

Second, there always exists a discount effect, which makes it costly to postpone a valuable reform. If a reform increases social welfare, and if the social welfare function involves discounting, postponing it means that there is a lower total social gain. Note however that if the social welfare function is a present discounted value of a flow of net social gains, and if the flows are negative in a slump but positive in a boom, then it makes perfect sense to wait for a boom. But if the flows are lower in a boom than in a slump, yet positive in both cases, one should go ahead with the reform as soon as possible.

Third, it is not clear at all whether the social cost of the job destructions implied by the reform are lower in booms. Consider the total number of jobs destroyed. One may well argue that it would be lower if the reform is implemented in a slump, for example if these jobs were to be destroyed even absent any reform. One can construct an example where there are two types of jobs, low productivity jobs and high productivity jobs, and where under regulation the former are worth keeping in expansion but not in recessions, when it it more profitable to pay dismissal costs. In such a world, deregulation will destroy jobs if implemented in an expansion, but not in a recession. In addition to the quantity of jobs being destroyed, one may consider the social cost of a job being destroyed. This cost may be negative, since these jobs are not profitable, but it may also be positive, since wages may exceed the worker's opportunity cost of labor, for reasons associated with incentive problems and bilateral monopoly ${ }^{3}$, and since that opportunity cost fails to reflect the true social value of search activities ${ }^{4}$. This does not mean that the reform is harmful, since it has other gains in the form of job creation, but that one should take into account the value of the jobs being destroyed, which may vary with macroeconomic conditions. Again, the direction of this variation is

\footnotetext{
${ }^{3}$ See Solow (1979), Shapiro and Stiglitz (1984), Bulow and Summers (1986), Lindbeck and Snower (1988).

${ }^{4}$ See Hosios (1990) and Caballero and Hammour (1996).
} 
unclear. On the one hand, it is harder to find another job in a slump, which suggests that the social loss from job destruction is larger in slumps. On the other hand, these effects are already reflected in the bargaining process, which typically implies that wages are lower in slumps. One may construct models where the difference between the social and private opportunity costs of labor is constant across the business cycles, implying that the excess social loss from destroying one job because of deregulation is acyclical.

\section{Macroeconomic conditions and the political support for reform}

We now turn to the next question, namely: when is the political support for the reform strongest? To answer that question, we shall first assume that incumbent employees are much more decisive politically than the unemployed. ${ }^{5}$ It is then useful to sort out several effects of labor market reform on their welfare.

The exposure effect: With the possible exceptions of reductions in the generosity of unemployment benefits, labour market reforms tend to favor the unemployed more than the employed, which they may harm. They consist in boosting job creation at the expense of the employed's bargaining power or their job security. This is why it is difficult to get political support for such reforms, since the employed are more numerous and better organized than the unemployed. However, there is one channel through which the welfare of the unemployed is taken into account by the employed, which is that they themselves are exposed to unemployment, and will benefit from reforms that boost job creation if they become unemployed in the future. This "exposure effect" has far-reaching implications. For exemple, it implies that reform may be impossible in an economy where the employed are overprotected by too tough regulations, since they then internalize very little of the unemployed's welfare. ${ }^{6}$ It also has implications for the timing of structural reforms. If it prevails, then the political support for reform is largest at times when the employed are most exposed, i.e. have the greatest probability of losing their job. Intuitively, this should be at the beginning of a

\footnotetext{
${ }^{5}$ The implications of this basic principle for the structure of regulation in political equilibrium and for the scope for reform are studied in Saint-Paul (2000). In particular, the constitutency effect and the identifiability effects are discussed at length.

${ }^{6}$ An example is analyzed in Saint-Paul (1993).
} 
recession, although we know that this probability has an important idiosyncratic component which is sizeable regardless of the business cycle. ${ }^{7}$

The identifiability effect: While on paper we can write a model where agents know exactly what will happen to them following a reform-for example they know their productivity and can perform the computations that their boss will make to find out whether to gbet rid of them or not--in practice the gains and losses from reform are not perfectly known, and the political support for reform will depend on the perceived distribution of such gains and losses. At one extreme, one could consider what would happen under a pure "veil of ignorance" where people consider that they could be in any position following the reform. In such a case everybody will maximize some representative expected utility level, and the reform will be politically viable if it increases social welfare, at least as defined by that utility. At the other extreme, one could consider a case where everybody knows for sure his situation after the reform. If a majority of voters lose a little, while the rest gain a lot, then the reform might be blocked, unless one can commit on a monetary transfer scheme to compensate the losers. By "identifiability", we then refer to the precision with which one knows one's net gain from the reform. A change in identifiability changes the political support for a reform, although it may either increase or decrease, depending on whether uncertainty redistributes gains in favor or not of the 'decisive' voter. Identifiability is also related to the business cycle, which helps to sort winners from losers. Let us go back to the example of unproductive jobs being destroyed in recessions even under regulation. Assume that people do not know for sure whether their job is productive or not, perhaps because their employer has a vested interest in not revealing it. Then if a reduction in employment protection is implemented in an expansion, all workers consider that they may lose their job with a positive probability after the reform; this will be the case if it turns out that their job is unproductive. This low identifiability may lead to all workers opposing the reform. On the other hand, if in a recession all unproductive jobs are destroyed, then at the end of the recession workers know for sure that they are in a productive job, and will not oppose the reform since it does not threaten their job. This example illustrates how recessions increase identifiability because they carry information about which jobs are productive and which jobs are not. In the case considered here identifiability is good for reform because it reduces the decisive voter's perceived probability that he is in a unproductive job, i.e. it redistributes gains in favor of the decisive voter. ${ }^{8}$ It suggests that the

\footnotetext{
${ }^{7}$ See Davis, Haltiwanger, and Schuh (1996).

${ }^{8}$ One can create examples where it goes the other way round, see Fernandez and Rodrik (1991).
} 
political support for reform is highest right after a recession, contrary to the exposure effect which is strongest right before a recession.

The constituency effect: By "constituency effect" I refer to the fact that labor market institutions may create their own constituency, which generates "status-quo" bias. That is, a number of people may be in a situation which makes it worth supporting an institution, and that situation only exists because of this institution. The existence of unproductive jobs under employment protection legislation is again a case in point: workers in unproductive jobs may support employment protection legislation for fear of losing their job if it were removed, but they would never hold such jobs if employment protection had not existed in the first place. Thus the economy may find itself in situations where employment protection is a political equilibrium, but where its absence would also be a political equilibrium-any of these two situations is sustainable if it is the status-quo, hence there is "status-quo bias".

In such a situation, reform is easier, the lower the "self-built" constituency, and its size typically varies with time and macroeconomic conditions. This variation does not imply that recessions or expansions are systematically better for reform; rather, that the whole past history of macroeconomic fluctuations will affect the political viability of the reform. The reason is that it is this past history which determines the current distribution of jobs across productivity levels, and thus the total number of unproductive jobs which would be destroyed after the reform. Consider, for example, a "vintage model" ${ }^{9}$ where new jobs are created at the highest possible productivity level, reflecting state-of-the-art technology. Assume a given job's productivity does not grow after the job has been created, while the technological frontier moves with time, due to technical change. In such a world, the least productive jobs are the oldest. A job's productivity relative to the frontier negatively depends on its age. The political constituency of job losers againts labor market reform will be larger, the larger the fraction of jobs older than a critical threshold. This fraction is likely to be larger if for example there is a boom followed by a long enough period of stagnation. Conversely, if there is a long enough recession followed by a boom, then at the end of the boom, there will be a relatively small proportion of "old jobs", since many of them were destroyed during the recession and most jobs have been created during the recent boom. Consequently, there is a "window of opportunity" for implementing a reduction in employment protection against fairly little opposition. However, the mass of "young" jobs will gradually age, and the workers

\footnotetext{
${ }^{9}$ Such a model is studied in Saint-Paul (2002).
} 
who hold them will eventually change their mind and oppose the reform, because they end up lagging behing in productivity, which threatens their jobs. Hence the window of opportunity offered by the boom will eventually be closed.

\section{Some evidence}

We hope to have convinced the reader that the view that good times are better for reform is too simplistic and that there is a variety of effects which go in different directions. This suggests that more could be learned by looking at the data. This is what I have done in SaintPaul (1996), where I have looked at the timing of a number of structural reforms which all changed the level of employment protection. The key lessons from this empirical study are as follows. First, most of the reforms which seem to be correlated with macroeconomic conditions are designed to be "marginal", in that they only affect the "flexible" tier of the labor market. Thus, we seldom observe across-the-board reductions in employment protection, but we often see liberalizations in the use of, say, temporary contracts. This reduces firing costs for the "marginal worker", who often does not have a regular contracts, but leaves the bulk of the workforce with its existing degree of protection. These reforms are a way to buy the political support of "insiders"10, and to spare them the threat of job loss. Second, there does seem to be an exposure effect, as suggested by the fact that virtually all these "marginal" reductions in firing costs took place at times when unemployment was rising, i.e. when the exposure of the employed to unemployment was high. At this stage one should point out that there is a difference between the level of unemployment, which may be quite high while the employed are quite protected, and its rate of change, which-unless there is strong growth in labor force participation-can only go up if the employed are at a risk of losing their job. While a high unemployment level increases the support for structural reforms because there are more unemployed people to support them, the effect is likely to be quite mild because the unemployed command little political power; on the other hand a high rate of change, i.e. a high exposure, as argued above, translates into a greater support from the employed, and is more likely to lead to reform. This is indeed what I found: while the level of unemployment has no explanatory power regarding the likelihood of reform, its rate of change makes reform more likely. Third, there are some instances of across-the-board

\footnotetext{
${ }^{10}$ See Saint-Paul (1993).
} 
reductions or increases in firing costs. This happens much less often than marginal changes, and does not seem correlated with the business cycle; rather, it is correlated with the government's ideology, with right-wing governments more likely to reduce firing costs and left-wing governments more likely to increase them. In contrast, ideology had little impact on marginal reforms.

\section{How should macroeconomic policy deal with reform?}

I now turn to the last question, namely the issue of the best macroeconomic policy in order to accompany a structural reform. In my view, the message is clear regarding this issue. From a macroeconomic perspective, a structural reform amounts to a reduction in the natural rate of unemployment, i.e. to the rate to which the economy converges in the absence of shocks. It is also known that the actual rate of unemployment does not adjust instantaneously to a change in the natural rate. A situation where the actual rate is above the natural rate is similar to a recession: resources are underutilized and prices tend to fall. Therefore, even though employment goes up following a structural reform, output nevertheless is below potential output, which makes it desirable to exert stimulus through monetary and fiscal policies. ${ }^{11}$ The deflationary impact of a structural reform may be greater in the case of a reduction in employment protection, since it is aggravated by the lump of unproductive jobs being destroyed after the reform.

These considerations imply that in the context of arrangements such as the European Monetary Union (EMU), labor market reforms may be problematic. ${ }^{12}$ An individual country considering a structural reform can no longer use monetary stimulus to accompany this reform. It could try to convince the European Central Bank (ECB) to lower interest rates, but other countries would object to that if they have different macroeconomic conditions. It may use fiscal policy, but this option is restricted by the stability pact and the fiscal stability program to which individual countries are committed. This impossibility of using macroeconomic policies in order to deal with structural reform increases the cost of these reforms, and some of them may be abandoned. In order to solve that problem, a natural

\footnotetext{
${ }^{11}$ This is also the conclusion reached by Bean (1998).

${ }^{12}$ See Saint-Paul and Bentolila (2001) for a more thorough discussion.
} 
solution would be a coordination of structural reforms among European states (or, rather, states of the Euro zone). In such a case, the European Central Bank could respond with a cut in interest rates, which would stimulate all the economies engaging in reforms. Therefore, belonging to EMU calls for more coordination of labor market policies across states. However, I am dubious about the likelihood of such coordination. The reason is that while being typically "rigid", labor market institutions differ quite a bit among member countries. Furthermore, they do not necessarily share the same analysis about the causes and cures of unemployment. For example, the idea that an increase in minimum wages should reduce unemployment, because it stimulated aggregate demand via workers' purchasing power, or that "work sharing" is a good policy to create jobs, would find a large number of supporters in some countries but not others. Before the stage of coordinated labour market reforms is reached, an important work of dissemination and vulgarization of economic analysis is needed. 


\section{REFERENCES}

Bean, Charles (1998), "The interaction of aggregate-demand policies and labour market reform", Swedish Economic Policy Review, 5, 2, 353-382

Bentolila, Samuel, and Giusppe Bertola (1990), "Firing costs and labor demand: How bad is Eurosclerosis ?", Review of Economic Studies 57, 381-402

Bertola, Giuseppe (1994), "Flexibility, Investment, and Growth", Journal of Monetary Economics, 34, 215-238

Bulow, Jeremy and Lawrence Summers (1986), "A theory of dual labor markets with application to industrial policy, discrimination and Keynesian unemployment", Journal of Labor Economics, 4, 1, 376-414

Caballero, Ricardo and Mohammad Hammour (1996), "On the timing and efficiency of creative destruction", Quarterly Journal of Economics

Davis, Steven, John Haltiwanger and Scott Schuch (1996), Job creation and job destruction. Cambridge MA: MIT Press

Fernandez, Raquel and Dani Rodrik (1991), "Resistance to reform: Status quo bias in the presence of uncertainty", American Economic Review, 81, 5, 1146-1155

Hopenhayn, Hugo and Richard Rogerson (1993), "Job turnover and policy evaluation: A general equilibrium analysis", Journal of Political Economy 101, 915-38

Lindbeck, Assar and Dennis Snower (1988), The insider-outsider theory of employment. Cambridge MA: MIT Press.

Saint-Paul, Gilles (1993), "On the political economy of labor market flexibility", NBER Macroeconomics Annual

Saint-Paul, Gilles (1995), "The high unemployment trap", Quarterly Journal of Economics (1996), "Exploring the political economy of labour market institutions",

Economic Policy

(1997), "The rise and persistence of rigidities", American Economic Review,

May

(2000), The political economy of labour market institutions. Oxford: Oxford

University Press

(2002), "The political economy of employment protection", Journal of Political Economy, 110, 672-704 
Saint-Paul, Gilles, and Samuel Bentolila (2001), "Will EMU increase Eurosclerosis?", in Charles Wyplosz, editor, The impact of EMU on Europe and the Developing Countries, WIDER, Oxford U. Press, 128-168.

Shapiro, Carl, and Joseph Stiglitz (1984), "Equilibrium Unemployment as a Worker's discipline device", American Economic Review, 74, 433-444

Solow, Robert (1979), "Another possible source of wage rigidity", Journal of Macroeconomics, 1, 79-82 


\section{IZA Discussion Papers}

\begin{tabular}{|c|c|c|c|c|}
\hline No. & Author(s) & Title & Area & Date \\
\hline 594 & $\begin{array}{l}\text { S. C. Wolter } \\
\text { M. Coradi Vellacott }\end{array}$ & $\begin{array}{l}\text { Sibling Rivalry: A Look at Switzerland with PISA } \\
\text { Data }\end{array}$ & 2 & $10 / 02$ \\
\hline 595 & $\begin{array}{l}\text { W. Arulampalam } \\
\text { A. L. Booth } \\
\text { M. L. Bryan }\end{array}$ & $\begin{array}{l}\text { Work-Related Training and the New National } \\
\text { Minimum Wage in Britain }\end{array}$ & 3 & $10 / 02$ \\
\hline 596 & $\begin{array}{l}\text { H. Görg } \\
\text { E. Strobl }\end{array}$ & $\begin{array}{l}\text { Relative Wages, Openness and Skill-Biased } \\
\text { Technological Change }\end{array}$ & 2 & $10 / 02$ \\
\hline 597 & $\begin{array}{l}\text { S. M. Fuess, Jr. } \\
\text { M. Millea }\end{array}$ & $\begin{array}{l}\text { Disentangling Pay and Productivity in a } \\
\text { Corporatist Economy: The Case of Germany }\end{array}$ & 5 & $10 / 02$ \\
\hline 598 & $\begin{array}{l}\text { D. Del Boca } \\
\text { A. Lusardi }\end{array}$ & $\begin{array}{l}\text { Credit Market Constraints and Labor Market } \\
\text { Decisions }\end{array}$ & 2 & $10 / 02$ \\
\hline 599 & $\begin{array}{l}\text { H. N. Mocan } \\
\text { B. Scafidi } \\
\text { E. Tekin }\end{array}$ & Catholic Schools and Bad Behavior & 5 & $10 / 02$ \\
\hline 600 & $\begin{array}{l}\text { J. S. Lauerová } \\
\text { K. Terrell }\end{array}$ & $\begin{array}{l}\text { Explaining Gender Differences in Unemployment } \\
\text { with Micro Data on Flows in Post-Communist } \\
\text { Economies }\end{array}$ & 4 & $10 / 02$ \\
\hline 601 & $\begin{array}{l}\text { Š. Jurajda } \\
\text { K. Terrell }\end{array}$ & $\begin{array}{l}\text { What Drives the Speed of Job Reallocation } \\
\text { during Episodes of Massive Adjustment? }\end{array}$ & 5 & $10 / 02$ \\
\hline 602 & L. Locher & Migration in the Soviet Successor States & 2 & $10 / 02$ \\
\hline 603 & $\begin{array}{l}\text { T. Andrén } \\
\text { B. Gustafsson }\end{array}$ & $\begin{array}{l}\text { Income Effects from Labor Market Training } \\
\text { Programs in Sweden During the 80's and 90's }\end{array}$ & 2 & $10 / 02$ \\
\hline 604 & $\begin{array}{l}\text { S. P. Jenkins } \\
\text { C. Schluter }\end{array}$ & $\begin{array}{l}\text { The Effect of Family Income during Childhood on } \\
\text { Later-Life Attainment: Evidence from Germany }\end{array}$ & 5 & $10 / 02$ \\
\hline 605 & C. Grund & $\begin{array}{l}\text { The Wage Policy of Firms - Comparative } \\
\text { Evidence for the U.S. and Germany from } \\
\text { Personnel Data }\end{array}$ & 5 & $10 / 02$ \\
\hline 606 & $\begin{array}{l}\text { M. Gerfin } \\
\text { M. Lechner } \\
\text { H. Steiger }\end{array}$ & $\begin{array}{l}\text { Does Subsidised Temporary Employment Get } \\
\text { the Unemployed Back to Work? An Econometric } \\
\text { Analysis of Two Different Schemes }\end{array}$ & 3 & $10 / 02$ \\
\hline 607 & Y. Zenou & How Do Firms Redline Workers? & 5 & $10 / 02$ \\
\hline 608 & G. Saint-Paul & $\begin{array}{l}\text { Economic Aspects of Human Cloning and } \\
\text { Reprogenetics }\end{array}$ & 3 & $10 / 02$ \\
\hline 609 & G. Saint-Paul & Cognitive Ability and Paternalism & 3 & $10 / 02$ \\
\hline 610 & A. Heitmueller & $\begin{array}{l}\text { Unemployment Benefits, Risk Aversion, and } \\
\text { Migration Incentives }\end{array}$ & 4 & $10 / 02$ \\
\hline 611 & G. Saint-Paul & $\begin{array}{l}\text { Some Thoughts on Macroeconomic Fluctuations } \\
\text { and the Timing of Labor Market Reform }\end{array}$ & 3 & $10 / 02$ \\
\hline
\end{tabular}

